\title{
SCIENCE AND THE NATIONAL EFFORT*
}

\author{
By the Right HoN. LORD HANKey, P.C., G.C.B., G.C.M.G., G.C.v.O.
}

$\mathrm{T}$ HE present position of scientific help in the prosecution of the War has been built up on foundations well and truly laid before war broke out, when the three great pillars of the permanent civil research organization of the Government were the Department of Scientific and Industrial Research, the Medical Research Council and the Agricultural Research Council.

Similarly, on the defence side there were important research organizations in the Admiralty ; the Ministry of Supply, which undertakes most of the research work for the War Office; the Air Ministry, which, however, has now handed over most of its research work to the Ministry of Aireraft Production; and the Ministry of Home Security, which occupies a position intermediate between the Service Departments and the Civil Depart. ments. In addition there was a good deal of research in the Civil Departments.

Just six months ago, with the approval of the Prime Minister, the late Mr. Neville Chamberlain, as Lord President of the Council, set up a Scientific Advisory Committee. It was the last official act of his long career. He had given much thought to the subject and when I last saw him he spoke of it with infectious enthusiasm : a characteristic instance of his far-sighted statesmanship. I am now drawing on my six months' experience as chairman of the new Committee. I had better begin by explaining its status. Besides the chairman, the Committee consists of Sir Henry Dale (the president of the Royal Society), Prof. A. V. Hill, M.P., and Prof. A. C. G. Egerton (joint secretaries of the Royal Society), together with the secretaries of the Department of Scientific and Industrial Research (Sir Edward Appleton), the Medical Research Council (Sir Edward Mellanby), and the Agricultural Research Council (Sir Edwin Butler, who unfortunately had to resign on grounds of ill-health); the chairman of the latter Council, however, Sir Thomas Middleton, has attended many of the Committee's meetings. In addition, at the request of the Committee, the Lord President of the Council invited Sir William Bragg, the former president of the Royal Society, whose term of office expired shortly after the formation of the Committee, to serve as an additional member until he had completed a period of twelve months. The joint secretaries are Prof.

- From a statement before the House of Lords on April 2.
W. W. C. Topley, a distinguished fellow of the Royal Society, with a colleague from the offices of the War Cabinet.

The Committee is in touch through the Royal Society with the great streams of scientific research and development ; through the representatives of Government research with Government activities ; and through the chairman and the Lord President, to whom the Committee reports, with the policy of the Government in these matters.

The question has been raised whether in constituting this Committee the Government has interpreted the term 'scientist' too narrowly. The reason for not including representatives of applied science was not a failure to appreciate its great importance to our war effort, but simply that the proposal did not fit into the Government's conception of the Scientific Advisory Committee. The Government had envisaged a small body with contacts with the whole of science, but not representing any particular section, to ensure the utmost use of science and men of science in the prosecution of the War. The representation of applied science with its many branches must have involved some enlargement of the Committee and would have altered the whole plan. The Govern. ment, however, is at present in touch with the professional societies concerned with a view to the possible establishment of a separate organiza. tion working in the field of applied science and in close touch with the Scientific Advisory Com. mittee, and an announcement may be expected before long.

The Committee has devoted itself mainly to the contribution of science in the war and will continue to do so. Nevertheless, the importance of the eventual use of science in problems of reconstruction has not been overlooked, and the Committee is in touch with the Minister without Portfolio, who is in charge of these matters.

At its first meeting the Committee decided to prepare as a background for future work a survey of the scientific activities of Government Departments.

In addition to obtaining written reports, the directors of scientific research of each of the Departments engaged mainly in war work were invited in turn to tell the Committee something of their activities. Sometimes they were accom. panied by staff officers of the Fighting Services, as representing the users of research. 
Owing to their secrecy, some of the subjects of discussion have to be confined to the smallest possible circle. To provide for this the Committee appointed a small Defence Services Panel composed of members who were already associated officially with secret Government research work.

In describing how far the assistance of men of science has been enlisted in the prosecution of the war, I shall return for a moment to what I called "the three great pillars of the permanent civil research organisations".

Thus the Department of Scientific and Industrial Research with its thirty-three advisory boards or committees, each dealing with a particular subject and each commanding the services of distinguished experts, disposes of a wealth of scientific talent. Their membership includes fifty-one fellows of the Royal Society. In addition, eleven members of the staff of the Department of Scientific and Industrial Research are fellows of the Royal Society. Eight fellows or university professors are retained as consultants, and fifteen university professors are engaged on extra-mural contracts in their own laboratories.

The ten Research Institutes for which the Department is responsible include the National Physical Laboratory, the Chemical Research Laboratory, and Laboratories or Stations for research on Building, Food Investigation, Fuel, Roads, Forest Products, Water Pollution and Pest Infestation. These, with the Geological Survey of Great Britain, provide facilities of immense importance to our war effort.

The Department renders assistance to the Fighting Services and to practically every Govern. ment Department ; for example, in home security problems, such as building and shelter construction and bomb disposal, and to the Ministry of Food in food storage, by combating pests and devising economical methods of packing to save space. Geology, among other contributions to our war effort, has informed authorities as to where sand is to be found in urban areas, thus saving transportation and cost.

Similarly the Medical Research Council, with its forty-five committees or sub-committees, its National Institute for Medical Research, its nine smaller research units, and its connexions with research in universities and elsewhere, is doing much to help our war effort. For example, in ooncert with the Ministry of Health and other Departments concerned, preparations were made before, and expanded during the War, with the view of safeguarding public health against risks arising from war conditions, such as concentrations of transferred populations in some districts, to say nothing of the effects of enemy action. An Emergency Public Health Laboratory Service was established with laboratories all over the country so that any unusual outbreaks of disease might be rapidly identified. Stocks of anti-sera and vaccines were accumulated and distributed throughout the country.

In a speech in this House in July 1939, I mentioned that the application of research in nutrition usually lagged some fifteen years behind discovery. This is no longer true. Under pressure of war conditions results of research are being applied in many directions. The Food Policy Committee of the War Cabinet makes good use of a Scientific Advisory Committee, and the Ministry of Food has a technical advisory staff.

The sphere of the Medical Research Council extends far beyond 'medicine' as this term is generally understood. It is concerned in all problems that affect man's health and efficiency. This enables the Council to assist the Defence Departments in problems relating to personnel and the use of science for increasing the efficiency and well-being of the men who have to operate machines such as aircraft, tanks and so forth. Excellent work of this kind has been done by a Flying Personnel Research Committee set up by the Air Ministry with the co-operation of the Medical Research Council nine months before the War.

The Scientific Advisory Committee has brought this aspect of science to the attention of the other Service Departments. The scope of the Flying Personnel Research Committee has now been expanded to cover naval personnel problems and a Military Personnel Research Committee has also been set up.

The Agricultural Research Council, with its twenty-five standing and technical committees of men of science with special experience of the matters with which they are concerned, with its Field Experimental Station, and with its great influence on the work of the twenty-three existing agricultural research institutes and other agricultural research subsidized by the Government, also makes an important contribution to our war effort.

I come now to the use of science in the military side of the war, where, as already mentioned, the Departments concerned are-the Admiralty; the Ministry of Supply ; the Ministry of Aircraft Production, and the Ministry of Home Security.

There is much in common between the methods of research and development of these Departments. Each has a director of research. The Ministry of Supply and the Ministry of Home Security have Central Advisory Committees to assist the directors in planning and carrying out the programme of work. The three Defence Departments are represented on them and the Committees include. 
unoffieial as well as official experts. The Ministry of Aircraft Production has an Aoronautical Research Committee, the successor of the Advisory Committee on Aeronautics established in 1909.

The First Lord of the Admiralty recently announced in another place that, in order to strengthen still further the co-operation between the Admiralty Research Department, outside scientific workers, and the Navy itself, the Board has decided to set up a Scientific Advisory Panel.

These Departments maintain research establishments, more than a score in number, all manned by highly qualified men of science. They work in close co-operation with one another, and one Defence Department will often refer a particular problem to an establishment maintained by another which has better facilities for the job. Each Department has frequent resort to the Department of Scientific and Industrial Research and the Medical Research Council, as well as to universities or other research institutes, or the research laboratories of producing firms. There is an increasing tendency to bring the large producing firms into co-operation at the earliest possible stage so that full advantage can be taken of their knowledge and experience.

I must also mention among Service research activities the Ordnance Board, which now acts under the Ministry of Supply. It is an interservice body with executive functions as to trials and calculations concerning fire-arms, their equipment, ammunition and armour. The Board derives originally from the Committee of Field Officers and Artillery under the ægis of the Board of Ordnance, 1518. Its standing members are officers of the three Services, and distinguished men of science are appointed from time to time as associate members.

Civil Departments may be divided for our purposes into those responsible for research establishments or for experiments or tests, and those which are not. Those Civil Departments which have no research establishments of their own usually have scientific committees, and both categories make wide use of the facilities of the Department of Scientific and Industrial Research, the Medical Research Council and/or the Agricultural Research Council.

The main conclusions of the Scientific Advisory Committee from its survey are that the scientific activities of the Government are far more extensive and far more effective than is commonly realized, and that much of the criticism is due to lack of knowledge of the facts. For example, one criticism is that the Government has failed to make effective use of the services of outside men of science. The Committee does not think this criticism justified. The names of nearly three hundred senior men of science associated in scientific work on behalf of the Government have come to its notice. This figure does not include the large numbers of younger men of science engaged continuously on war work in the numerous research establishments maintained by the Government, or in the Services.

It would be too much to claim that the fullest use is being made of every senior scientific worker, but in the more important fields the majority of those especially well fitted to assist our war effort have been given an opportunity to do so. In some fields, however, opportunities may not yet have appeared, and the Committee reports that there has been a feeling of frustration among individuals. In the case of junior scientific workers the demand in different fields of science varies and fluctuates so widely that it is impossible, except very gradually, to absorb in work of national importance all those who are anxious to employ their special knowledge in some form of war activity. Some help, however, is afforded by training schemes whereby men of science trained in one subject, where opportunities for war service are few, can be given rapid training in an allied science.

Having recorded general satisfaction with the range and effectiveness of the Government's scientific activities, the Committee comments that some of the existing forms of organization have proved more effective than others. It directs attention to the effective and economical methods developed by the Department of Scientific and Industrial Research and the Medical Research Council, the success of which it believes is largely due to the fact that they have been allowed full scientific freedom and complete control over the funds at their disposal.

The Agricultural Research Council, as at present organized, has not the same freedom of initiative and action. Believing the scientific development of agriculture to be of the greatest importance to the country, both during and after the War, the Scientific Advisory Committee has considered how much freedom might be secured, and the Council's activities thus made more effective. In consultation with the Minister of Agriculture and Fisheries and the Secretary of State for Scotland, the Committee has drawn up proposals for strengthening fundamental research and ensuring a more ready application of promising scientific discoveries to agricultural practice (see p. 447 of this issue).

So far as the scientific activities of the Defence Services are concerned, the points to which the Committee attaches the greatest importance are the following :

(1) Provision in the organization of departmental scientific staffs for regular consultation 
with a strong advisory council or committee which includes outside scientific experts.

(2) The utmost possible use of the facilities of the Department of Scientific and Industrial Research and the Medical Research Council. This is already in operation and is likely to be extended.

(3) A much wider and more intensive study of those problems connected with early and adequate pravision for the efficiency of personnel in the design of new instruments of war.

(4) The close co-operation at every stage of research, development and production between the operational and scientific staffs.

I come now to one or two other matters that have engaged the attention of the Scientific Advisory Committee.

The Committee has suggested the names of men of science for particular tasks or to assist in specific investigations to a number of Government Departments, as well as to the British Council. In this connexion I must mention the invaluable work of the Central Register of the Ministry of Labour and National Service, for the utilization in Government Departments and elsewhere of persons with scientific, technical, professional and higher administrative qualifications. With the aid of the Government Departments concerned, and of various outside organizations including the Royal Society, and of a very strong advisory council, the register is very comprehensive.

The question of enlisting scientific researchers of other countries and refugee aliens has been raised. The Scientific Advisory Committee has given a good deal of attention to this question. It presents obvious difficulties. If, as I have said, we have not absorbed into the Government war effort all our own men of science, we cannot absorb unlimited numbers of refugee men of science. In addition, much of the research work is so secret that precautions have to be taken. Nevertheless, a number of refugee specialists are employed in research laboratories, mainly on the medical side so far as the Government is concerned, but also in industry.

Scientific co-operation with the Dominions, India and the Colonies is satisfactorily provided for. Canada, of course, occupies a position of spacial importance, and her collaboration in the scientific field is proving of the greatest value. There is also in Canada scope for close co-operation in scientific matters with the United States. Prof. R. H. Fowler has been in Canada for some eight months, and is now being relieved by Sir Lawrence Bragg -a colleague of equal distinction.

The Committee has also taken a deep interest in the question of co-operation in scientific matters with the United States. At an early meeting it discussed the matter with Prof. John Fulton of
Yale University, who was on a visit to Great Britain on behalf of the U.S. National Research Council. A member of the Committee, Prof. A. V. Hill, had already been to the United States on a scientific liaison mission, and the Committee had discussions both with him and with Sir Henry Tizard, on his return from a similar mission.

After consideration of the Committee's proposals, and after consultations with the proper authorities in the United States, a comprehensive scheme has been put in operation.

His Majesty's Government has elected and sent Dr. C. G. Darwin, the director of the National Physical Laboratory, as director of a Central Scientific Office working under the direction of the British Supply Council in North America to collaborate with United States research bodies, to act as a channel for exchange with the appropriate United States authorities of technical and scientific information, and generally to co-ordinate scientific and technical inquiries to and from the United States authorities, except on those Service questions that are dealt with through the Service attachés. The scientific mission to Canada is closely linked with this system so as to ensure a complete interchange of scientific and technical information between the three countries.

At the same time President Roosevelt has sent to Great Britain Dr. J. B. Conant, president of Harvard University, to establish a corresponding mission in this country, and Dr. Conant and some of his colleagues have attended meetings of the Committee. This mission has received a very warm welcome, and arrangements have been made to facilitate its work. Its permanent secretary, Dr. Hovde, knows his way well here, for, as a Rhodes Scholar, he spent some years at Oxford. Accredited American men of science have already arrived in Great Britain.

The historians of war from the earliest time pay their tributes to the importance of science. The theme of a long chapter by Polybius on Archimedes is that "The genius of one man is more effective than any number whatsoever". In these days no one man, whatever his genius, can cover more than a fraction of the immense field of science in war, of which I have only been able to give the faintest impression in the time at my disposal. We require thousands of scientific workers.

We are engaged in a death struggle with an enemy who boasts, with justification, of his achievements in the field of science. Our men of science are at least as good as his, and with the aid of the scientific resources of the Empire, and especially of the Unites States, we are building a scientific equipment which is destined to play an ever-increasing part in our war effort and in the period of reconstruction that must come thereafter. 